\title{
inat \\ Copper Supported on Mesoporous Structured Catalysts for NO Reduction
}

\author{
Mariana B. S. Felgueiras ${ }^{1}$, João Restivo ${ }^{1}{ }^{1}$, Juliana P. S. Sousa ${ }^{2}$, Manuel F. R. Pereira ${ }^{1}{ }^{1}$ \\ and Olívia S. G. P. Soares $1, * \mathbb{C}$
}

1 Laboratory of Separation and Reaction Engineering-Laboratory of Catalysis and Materials (LSRE-LCM), Departamento de Engenharia Química, Faculdade de Engenharia, Universidade do Porto, Rua Roberto Frias, 4200-465 Porto, Portugal; mbsf@fe.up.pt (M.B.S.F.); jrestivo@fe.up.pt (J.R.); fpereira@fe.up.pt (M.F.R.P.)

2 International Iberian Nanotechnology Laboratory (INL), Avenida Mestre José Veiga, 4715-330 Braga, Portugal; juliana.sousa@inl.int

* Correspondence: salome.soares@fe.up.pt

check for

updates

Citation: Felgueiras, M.B.S.; Restivo, J.; Sousa, J.P.S.; Pereira, M.F.R.; Soares, O.S.G.P. Copper Supported on Mesoporous Structured Catalysts for NO Reduction. Catalysts 2022, 12, 170. https://doi.org/10.3390/ catal12020170

Academic Editors: Soghomon Boghosian and Jean-François Lamonier

Received: 3 January 2022

Accepted: 24 January 2022

Published: 28 January 2022

Publisher's Note: MDPI stays neutral with regard to jurisdictional claims in published maps and institutional affiliations.

Copyright: (C) 2022 by the authors. Licensee MDPI, Basel, Switzerland. This article is an open access article distributed under the terms and conditions of the Creative Commons Attribution (CC BY) license (https:// creativecommons.org/licenses/by/ $4.0 /)$.

\begin{abstract}
Nitrogen oxides $\left(\mathrm{NO}_{\mathrm{x}}\right)$ are one of the pollutants of greatest concern in terms of atmospheric contamination and, consequently, human health. The main objective of this work, is the synthesis of structured carbon catalysts, introducing on their surface metals and nitrogen groups, catalytically active in NO reduction. Structured catalysts represent an attractive alternative to powder catalysts because they have better thermal stability and lower pressure drop. The catalysts were synthesized by coating a melamine foam using precursor solutions of carbon xerogels with and without nitrogen (using melamine and urea as precursors), and impregnated with transition metals ( $\mathrm{Fe}, \mathrm{Ni}$ and $\mathrm{Cu}$ ). The introduction of nitrogen and metals modified the textural properties of the materials. Samples synthesized with melamine presented the highest amount of nitrogen, while the highest content of copper, found to be the most active transition metal for NO reduction, was found in structured catalysts impregnated with urea. The presence of transition metals in catalysts is essential for the reduction of $\mathrm{NO}$ to $\mathrm{N}_{2}$ and the introduction of nitrogenous precursors makes this evident. The synthesis and application of carbon-supported structured catalysts containing transition metals for NO reduction is demonstrated in this work for the first time, as well as the study of the factors influencing their performance.
\end{abstract}

Keywords: nitric oxide; catalytic reduction; structured catalyst; carbon; transition metal catalyst; SCR

\section{Introduction}

Pollution is one of the problems with significant impact in the 21st century caused by excessive human consumption, directly affecting the climate, the quality of drinking water, agricultural production and, consequently, the health of living beings. Nitrogen oxides $\left(\mathrm{NO}_{\mathrm{x}}\right)$ are considered one of the pollutants that cause the greatest concerns in terms of atmospheric contamination, as they contribute to photochemical smog, acid rain, degradation of the ozone layer and the greenhouse effect [1]. Nitrogen monoxide (NO) represents about $95 \%$ of the total nitrogen oxides emitted and is a colorless and odorless gas that is released into the atmosphere due to incomplete combustion processes of fuels used in stationary and mobile sources [2].

Several measures have been applied to reduce their emissions, essentially in the chemical and transport industries, to prevent these gases from being emitted into the atmosphere. The methods used to reduce $\mathrm{NO}_{\mathrm{x}}$ emission are divided into two main groups: primary and secondary methods. The former reduce $\mathrm{NO}_{x}$ emissions by up to $50 \%$ and are preventive measures that consist of changing operating conditions and organizing the process during pre-combustion and combustion [3]. The latter are applied after combustion and reduce up to $100 \%$ of the nitrogen oxides already formed [2]. 
Secondary measures for $\mathrm{NO}_{x}$ elimination include selective catalytic reduction (SCR), where $\mathrm{NO}$ is directly reduced to $\mathrm{N}_{2}$ using different external reducing agents over different catalysts such as ammonia over a modified zeolite [4], $\mathrm{V} / \mathrm{Mo}$-Ti [5] and $\mathrm{V}_{2} \mathrm{O}_{5} / \mathrm{TiO}_{2}$-carbon nanotube [6], urea over activated carbon supported metal oxide [7], hydrocarbons [8], hydrogen [9] or carbon materials, where carbon acts as a reducing agent, support and catalyst (Equations (1) and (2)) [10,11].

$$
\begin{aligned}
& 2 \mathrm{NO}+\mathrm{C} \rightarrow \mathrm{N}_{2}+\mathrm{CO}_{2} \\
& 2 \mathrm{NO}+2 \mathrm{C} \rightarrow \mathrm{N}_{2}+2 \mathrm{CO}
\end{aligned}
$$

The use of carbon in SCR makes the process more economical and environmentally friendly; however, it presents as disadvantages the need to reach temperatures above $500{ }^{\circ} \mathrm{C}$ for conversion to occur, which causes the consumption of carbon by combustion at high levels of oxygen [11,12]. Reducing the reaction temperature proved to be the most effective method to minimize carbon combustion by $\mathrm{O}_{2}$, which simultaneously affects the catalytic performance [11].

The use of transition and alkali metals in carbon-based catalysts significantly reduces the activation energy of the reactions and increases the adsorption capacity of NO [13]. During the reaction of $\mathrm{NO}$ with carbon, the impregnated metal participates in the redox mechanism, being oxidized by NO and reduced by carbon [14]. E. Bailón-García et al. [14] prepared metal $(\mathrm{Fe}, \mathrm{Co}$, and $\mathrm{Cu}$ ) catalysts dispersed on carbon xerogels to study the activity of the materials in $\mathrm{NO}_{\mathrm{x}}$ reduction and verified that the complete $\mathrm{NO}$ conversion, with the highest selectivity, was attained at $230{ }^{\circ} \mathrm{C}$ in the presence of $\mathrm{Cu}$.

Nitrogen doping of carbon materials increases the surface electrons density and the ability to donate them, which results in a better performance of the catalysts [15], improving the catalytic and adsorbent properties of activated carbons for $\mathrm{SO}_{\mathrm{x}}, \mathrm{NO}_{\mathrm{x}}$ and $\mathrm{CO}_{2}[16,17]$. In the case of carbon xerogel (CX), nitrogen doping can be accomplished by introducing a nitrogen-containing precursor into the formation of the organic structure of the carbon xerogel through sol-gel polycondensation [17]. Activation or impregnation with transition metals and/or conductive polymers can facilitate the incorporation of the nitrogen atom into the carbon matrix to form more active nitrogen-carbon structures with high surface area, enhancing the catalytic performance of the carbon material [11,13-15,18-20].

Monolithic structured catalysts are highly porous and have a structure of uniform and random blocks consisting of narrow channels in parallel or zigzag [21,22]. They can be ceramic or metallic structures. Ceramics show better porosity, good adhesion to the coating and thermal stability, while metallic ones show better heat transfer, mechanical stability, wall thickness and total volume [21]. Foams are another type of structured catalyst characterized as either "closed cell", where the cells are connected through solid faces, or "open cell", which have solid margins and open faces, that allows the fluid transfer from one cell to the other decreasing the flow resistance. Therefore, catalysts in the form of "closed cell" foams are more favorable to catalysis processes [23]. Melamine foam (MF) is a type of ultra-fine fiber foam and has the benefits of low bulk density, high density structure and flexibility, excellent mechanical properties and porous structure, even after high temperature carbonization [18]. These structures, not catalytically active, serve as a support to give rise to a structured catalyst prepared by coating an active catalytic phase. The method of synthesis of the structured catalyst is a major factor in the properties and efficiency of the catalysts to be obtained, and some examples are precipitation, impregnation, lyophilization and sol-gel polycondensation [24].

The focus of this work was the preparation of structured catalysts based on carbon materials, which represent an attractive alternative to conventional powder catalysts because they have better heat and mass transfer, reduced pressure drop and superior thermal and mechanical stability [21,25-27]. The primary objective is the synthesis of structured carbon catalysts catalytically active in the reduction of NO. These catalysts were synthesized by coating melamine foams and cordierite monoliths $(\mathrm{CM})$ using precursor solutions of 
nitrogen-free and nitrogen-doped carbon xerogels. Initially, the performance of the carbon catalysts in powder form was assessed in NO reduction where the characteristics of the carbon and N-doped carbon xerogels were assessed. The more active catalysts were then impregnated with transition metals $(\mathrm{Fe}, \mathrm{Ni}$, and $\mathrm{Cu})$. Then, the best performing samples were prepared as structured catalysts by coating melamine foams and cordierite monoliths.

\section{Results and Discussion}

\subsection{Catalysts Characterization}

Table 1 shows the textural properties of the synthesized materials in terms of specific surface area $\left(\mathrm{S}_{\mathrm{BET}}\right)$, specific surface area of mesopores $\left(\mathrm{S}_{\text {meso }}\right)$, specific volume of micropores $\left(\mathrm{V}_{\text {micro }}\right)$ and total pore volume $\left(\mathrm{V}_{\mathrm{p}}\right)$.

Table 1. Textural properties of the catalytic materials.

\begin{tabular}{ccccc}
\hline Sample & $S_{\text {BET }} / \mathbf{m}^{\mathbf{2}} \mathbf{g}^{-\mathbf{1}}$ & $S_{\text {meso }} / \mathbf{m}^{\mathbf{2}} \mathbf{g}^{-\mathbf{1}}$ & $V_{\text {micro }} / \mathbf{c m}^{\mathbf{3}} \mathbf{g}^{-\mathbf{1}}$ & $V_{\mathbf{p ~ p} / \mathbf{p o}=\mathbf{0 . 9 5}} / \mathbf{c m}^{\mathbf{3}} \mathbf{g}^{-\mathbf{1}}$ \\
\hline CX & 636 & 211 & 0.17 & 1.30 \\
CX_Fe & 628 & 203 & 0.17 & 1.30 \\
CX_Ni & 599 & 199 & 0.16 & 1.30 \\
CX_Cu & 590 & 182 & 0.17 & 1.30 \\
CX_M_Cu & 524 & 55 & 0.19 & 0.29 \\
CX_U_Cu & 404 & 79 & 0.14 & 0.20 \\
MF_10Cu & 614 & 199 & 0.17 & 0.89 \\
MF_M_10Cu & 542 & 65 & 0.20 & 0.28 \\
MF_U_10Cu & 796 & 140 & 0.27 & 0.35 \\
MF_U_20Cu & 536 & 140 & 0.18 & 0.40 \\
MF_U_30Cu & 471 & 48 & 0.18 & 0.22 \\
CM_U_10Cu & 71 & 8 & 0.03 & 0.04 \\
\hline
\end{tabular}

Values obtained by total catalyst mass.

The original CX demonstrates the highest specific surface area, $636 \mathrm{~m}^{2} \mathrm{~g}^{-1}$. The $S_{\mathrm{BET}}$ decreased after impregnation with $\mathrm{Fe}, \mathrm{Ni}$ and $\mathrm{Cu}$, respectively, and the micropore volumes did not change significantly. This phenomenon is due to the introduction of the metals, which partially block the pores, making part of the CX surface inaccessible for $\mathrm{N}_{2}$ adsorption [10]. Samples synthesized with nitrogen precursors and impregnated with copper also showed a decrease in specific surface areas due to blocking of access to the surface porosity during analysis [28].

The MF_10Cu (without nitrogen) sample presents a $S_{\text {BET }}$ of $614 \mathrm{~m}^{2} \mathrm{~g}^{-1}$ and the CX_Cu of $590 \mathrm{~m}^{2} \mathrm{~g}^{-1}$, while for the MF_M_10Cu (prepared with melamine) and in CX_M_Cu it corresponds, respectively, to $542 \mathrm{~m}^{2} \mathrm{~g}^{-1}$ and $524 \mathrm{~m}^{2} \mathrm{~g}^{-1}$. However, in MF_U_10Cu (synthesized with urea) the $S_{\mathrm{BET}}$ is $796 \mathrm{~m}^{2} \mathrm{~g}^{-1}$, which differs considerably from the obtained for the respective CX_U_Cu, $404 \mathrm{~m}^{2} \mathrm{~g}^{-1}$, which must be related to the strong adhesion of urea to the structured materials due to the urea-melamine-formaldehyde interaction generated during the impregnation of the carbon xerogel solution with urea in the melamine foam [27-29].

The specific surface areas and the volume of micropores decreased with the increase in the amount of metal, which partially block the pores, making part of the CX surface inaccessible for $\mathrm{N}_{2}$ adsorption [10,11]. In contrast, the CM_U_10Cu presents the lowest $S_{\mathrm{BET}}$ and the micropore volume almost zero, due to the contribution of the CM support, since it has a specific surface area of $1 \mathrm{~m}^{2} \mathrm{~g}^{-1}$ [27].

The introduction of the nitrogen precursor, urea or melamine, during the synthesis of CX allows obtaining materials with nitrogen in their structure, 2.1 and $4.9 \%$ (wt.\%), respectively, for sample CX_U and CX_M. The increase in the nitrogen amount in the melaminedoped sample can be explained by the fact that the molecular structure of melamine allows the incorporation of more $\mathrm{N}$-functionalities when compared with urea [30].

The copper content determined through ICP-OES for each sample is listed in Table 2. 
Table 2. Copper and nitrogen content determined by ICP-OES and XPS.

\begin{tabular}{cccc}
\hline Sample & \%ICP-OES Cu & \%XPS Cu & \%XPS N \\
\hline CX_M & - & - & 2.3 \\
CX_U & - & - & 1.4 \\
CX_Cu & 14 & - & - \\
MF_10Cu & 3.3 & 0.98 & - \\
MF_M_10Cu & 4.6 & 1.3 & 3.2 \\
MF_U_10Cu & 6.7 & 1.5 & 2.3 \\
MF_U_20Cu & 9.4 & - & 2.3 \\
MF_U_30Cu & 17 & - & 2.3 \\
CM_U_10Cu & 3.1 & - & - \\
\hline
\end{tabular}

Values obtained by total catalyst mass.

In $\mathrm{CX}$ powders, the difference of the $14 \% \mathrm{Cu}$ obtained through ICP-OES from the expected $10 \% \mathrm{Cu}$ is associated with deviations in the synthesis. The percentage of copper in the structured catalysts increases in the order MF_10Cu $<$ MF_M_10Cu $<$ MF_U_10Cu, revealing that MF_U_10Cu demonstrates the greatest capacity for copper impregnation, as it has a higher specific surface area than the other MF [31]. As expected, in materials where 20 and $30 \% \mathrm{Cu}$ was impregnated, the percentages obtained were higher than those obtained for MF_U_10Cu.

The surface composition analyzed by XPS (Table 2) revealed a similar trend to that obtained through EA and ICP-OES, since the highest percentage of nitrogen is verified in samples with melamine, and the amount of copper also increases in the order MF_10Cu < MF_M_10Cu < MF_U_10Cu. However, the results obtained through this analysis are lower than those obtained previously, which can be explained by the fact that this technique provides information on the elemental composition and nature of chemical bonds of atoms on the surface of materials (up to 10-15 nm), revealing that nitrogen and copper are not homogeneously distributed on the surface and the bulk of the MF. Concerning N-functionalities, quaternary nitrogen $(\mathrm{QN})$, pyrrolic (N5) and pyridine (N6) groups are typical structures formed in carbon materials prepared between 550 and $900{ }^{\circ} \mathrm{C}$ [32].

Thermogravimetric analyses were performed under an air flow up to $900{ }^{\circ} \mathrm{C}$ for $\mathrm{CX}$ (Figure 1a) and MF (Figure 1b) to determine the thermal stability of the catalysts.

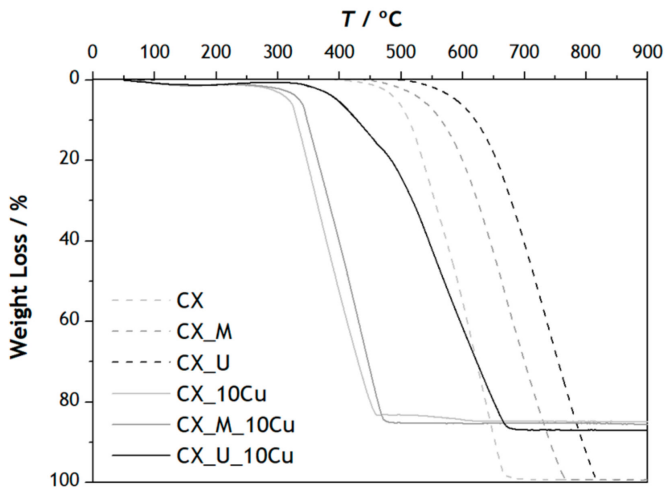

(a)

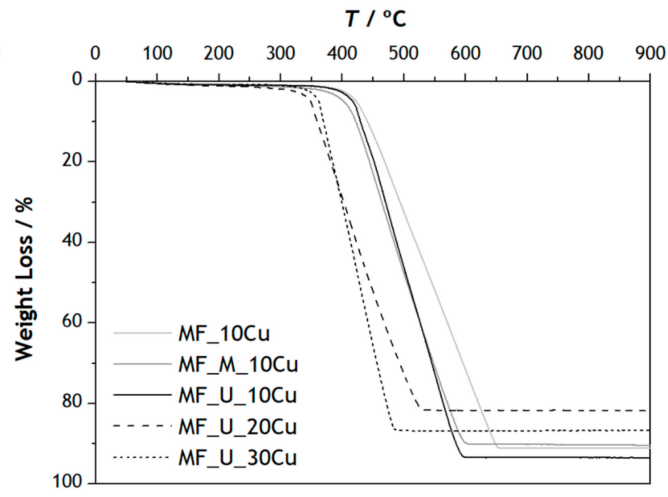

(b)

Figure 1. Weight loss during thermogravimetric analysis of (a) CX and (b) MF.

In the original CX there is a loss of mass starting from $440^{\circ} \mathrm{C}$, while in CX_M and CX_U combustion starts at 460 and $520^{\circ} \mathrm{C}$, respectively. Complete combustion of the samples occurs above $600^{\circ} \mathrm{C}$ in CX without nitrogen and above $750{ }^{\circ} \mathrm{C}$ in CX_M and CX_U. XPS analysis reveals no significant differences regarding the type of nitrogen groups; therefore, the introduction of these groups in the CX, either with melamine or urea as a precursor, gives thermal stability to the materials in an oxidizing atmosphere and the differences are related to the amount of nitrogen present in the materials [33]. Combustion of CX_10Cu, 
CX_M_10Cu and CX_U_10Cu started at $260^{\circ} \mathrm{C}$, a value considerably lower than that of CX, CX_M and CX_U, while the gradual increase in Cu content led to slighter changes in combustion temperature. These results suggest that there is an interaction between $\mathrm{O}_{2}$ present in the air and copper, leading to a burn of the sample at lower temperatures [34]. MF samples were found to be stable up to $350{ }^{\circ} \mathrm{C}$, suggesting that the structured catalysts were more thermally stable than their powder CX counterparts, with combustion starting at $260{ }^{\circ} \mathrm{C}[21,25]$.

Figure 2 shows the images obtained through scanning electron microscopy of an as-received foam (Figure $2 \mathrm{a}$ ) and the foams that were in contact with the nitrogen-free CX solution (Figure 2b,c), with melamine (Figure 2d) and with urea (Figure 2e).
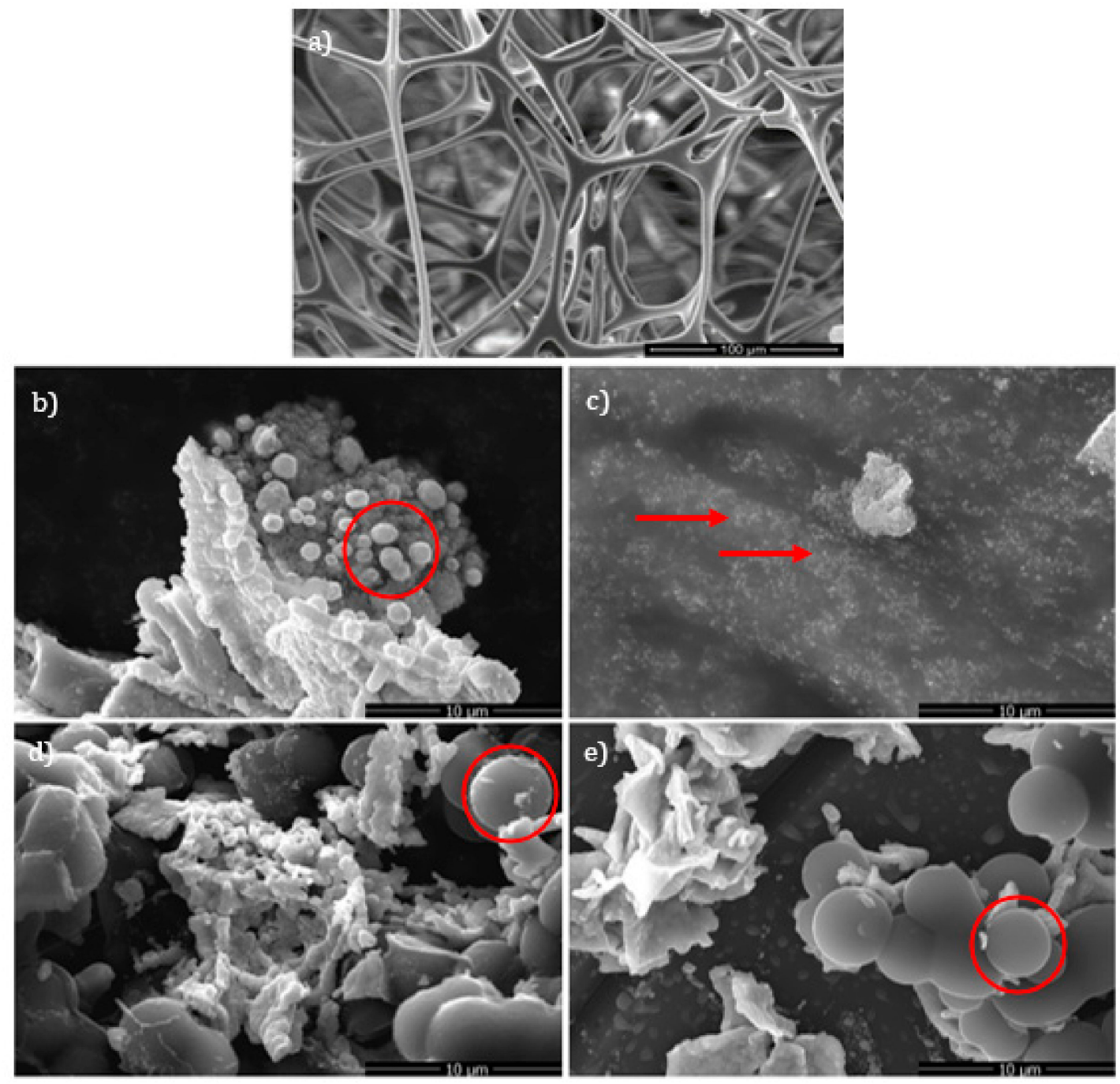

Figure 2. SEM images of (a) MF, (b) and (c) MF_10Cu, (d) MF_M_10Cu and (e) MF_U_10Cu.

As expected, all samples have similar morphologies [17]. Figure 2a shows the structure of the foam without any coating. In Figure $2 b, d, e$, this structure is covered by the respective $C X$ solutions. As mentioned by other authors, it is proven that $C X$ is made up of interconnected spherical particles (circled), and the MFs have a porous structure in the shape of a honeycomb [34,35]. Figure 2c shows bright spots (marked with arrows) corresponding to the copper particles, which indicates a homogeneous copper distribution throughout the matrix. 


\subsection{Catalytic Tests}

\subsubsection{Powder Catalysts}

Blank tests (without catalyst) were carried out to evaluate the influence of the geometry of the reactors used for powder catalysts (CX) and structured catalysts (MF and CM), with diameters of 0.7 and $2.6 \mathrm{~cm}$, respectively. The homogeneous conversion of NO (Figure A1) was also assessed and differs only $1 \%$ between the two tests, being $14 \%$ for the $0.7 \mathrm{~cm}$ reactor and $13 \%$ for the $2.6 \mathrm{~cm}$ reactor (Appendix A).

The impregnation of metals on carbon-based catalysts increases the adsorption capacity of NO in the materials and reduces the reaction temperature significantly $[13,14]$. Accordingly, the catalytic performance of $\mathrm{Fe}, \mathrm{Ni}$ and $\mathrm{Cu}$ supported on $\mathrm{CX}$ was assessed in the reduction of NO.

In Figure 3 it can be seen that the CX prepared without metals does not show significant activity in the catalytic reduction of NO up to the maximum temperature used in this study, $350{ }^{\circ} \mathrm{C}$, and the transition metals studied were able to reduce $\mathrm{NO}$ into $\mathrm{N}_{2}$ through carbon in the presence of oxygen [11,12]. The CX_Fe and CX_Ni samples showed a maximum conversion of 56 and 54\%, respectively, for the maximum reaction temperature, and the sample CX_Cu showed complete conversion at $324{ }^{\circ} \mathrm{C}$. Illán-Gómez et al. [20] studied the catalytic reduction of $\mathrm{NO}_{\mathrm{x}}$ through transition metals $(\mathrm{Fe}, \mathrm{Co}, \mathrm{Ni}$ and $\mathrm{Cu}$ ) on a carbon support and the effect of oxygen on catalytic properties of metals at $300{ }^{\circ} \mathrm{C}$, reporting identical values $\left(14,26\right.$ and $44 \%$ at $300{ }^{\circ} \mathrm{C}$ for $\mathrm{Fe}, \mathrm{Ni}$ and $\mathrm{Cu}$, respectively), but slightly lower, than those presented in this work. The catalytic activity of the metal for the NO reduction by carbon is affected by the tendency of the metal to be oxidized by NO and by the ease of the resulting metal oxide of being reduced by carbon [20]. Although the largest specific surface area is verified in CX_Fe $\left(628 \mathrm{~m}^{2} \mathrm{~g}^{-1}\right)$ and the smallest in CX_Cu $\left(590 \mathrm{~m}^{2} \mathrm{~g}^{-1}\right)$, the copper impregnated material exhibited better catalytic performance for NO reduction [14].

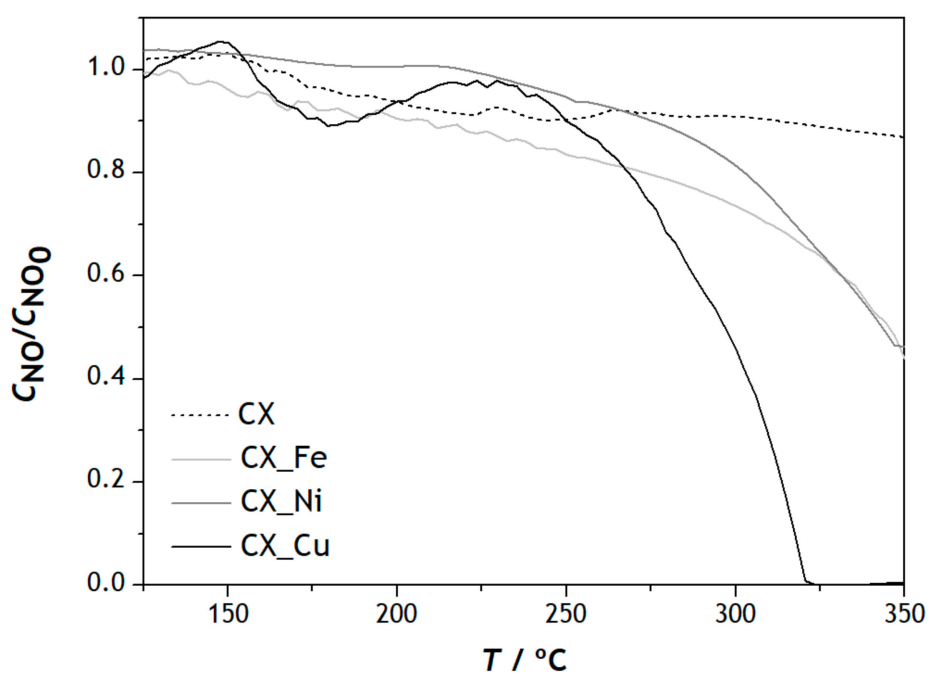

Figure 3. $\mathrm{NO}$ concentration in the presence of $\mathrm{CX}$ with metals with $[\mathrm{NO}]=1000 \mathrm{ppm}$ in $\mathrm{He}$ with $5 \%$ of $\mathrm{O}_{2}$.

\subsubsection{Powder N-Doped Catalysts}

All copper-based materials presented high conversion values than their metal-free counterparts (Figure 4); however, only those supported on CX and CX_M showed 100\% conversion below the maximum reaction temperature of $350{ }^{\circ} \mathrm{C}$. CX_Cu achieves full conversion at $324{ }^{\circ} \mathrm{C}$, the CX_U_Cu sample allows $90 \%$ to be obtained at $332{ }^{\circ} \mathrm{C}$ and the CX_M_Cu achieves $100 \%$ conversion at $329^{\circ} \mathrm{C}$. 


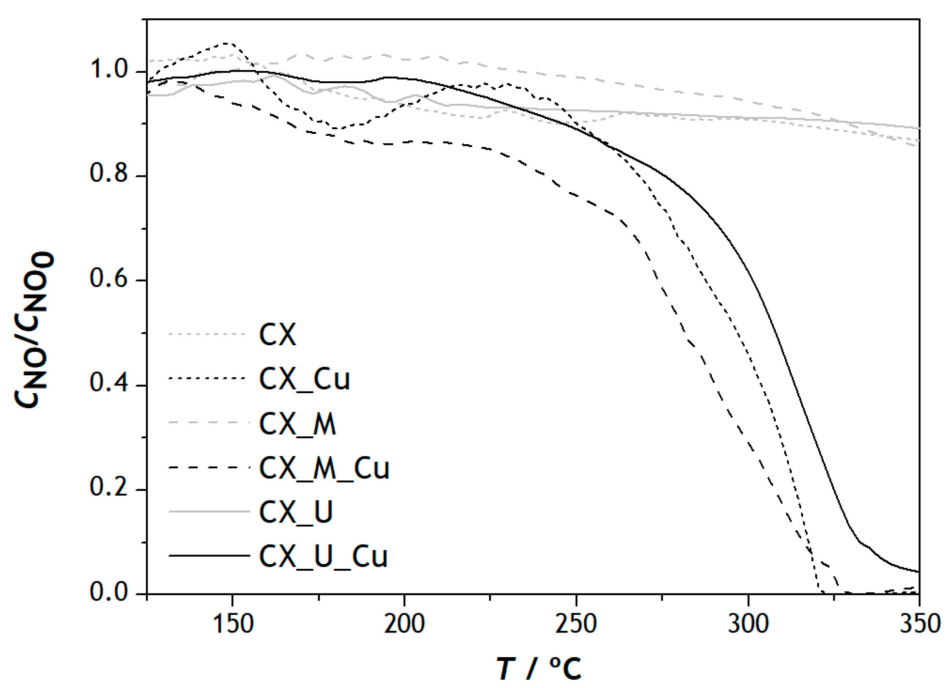

Figure 4. NO concentration in the presence of CX and CX_N with and without metals with $[\mathrm{NO}]=1000 \mathrm{ppm}$ in $\mathrm{He}$ with $5 \%$ of $\mathrm{O}_{2}$.

The influence of the specific surface area and the amount of nitrogen was assessed in Figure 5. As all materials have the same amount of copper, samples are more catalytically active the greater the specific surface area and the greater the percentage of nitrogen in the CX [31].

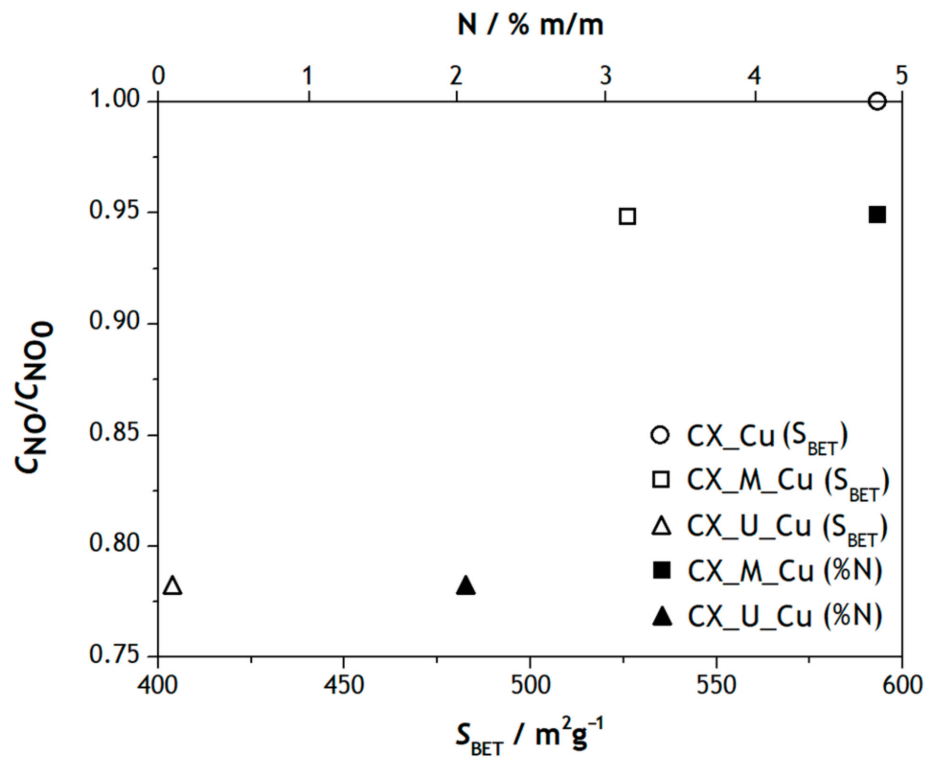

Figure 5. NO concentration in the presence of $C X$ and CX_N with copper with $[N O]=1000$ ppm in He with $5 \%$ of $\mathrm{O}_{2}$ as a function of the specific surface area and the amount of nitrogen.

\subsubsection{Structured Catalysts}

Figure 6 shows the profiles obtained in the NO reduction reaction by catalysts structured with $\mathrm{MF}$ at $350{ }^{\circ} \mathrm{C}$.

Table 3 summarizes the conversions obtained by the MF samples at $350^{\circ} \mathrm{C}$, the amount of the structured catalysts used in the reactions and the conversions as a function of these values, the specific surface area and the copper mass are also listed. 


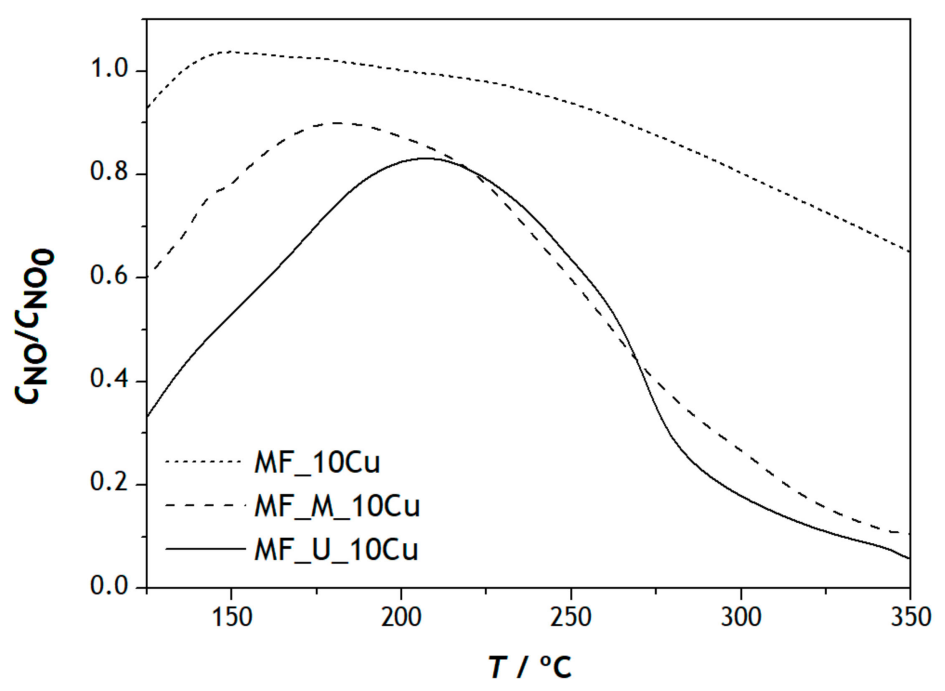

Figure 6. $\mathrm{NO}$ concentration in the presence of $\mathrm{MF}$ with $[\mathrm{NO}]=1000 \mathrm{ppm}$ in He with $5 \%$ of $\mathrm{O}_{2}$.

Table 3. NO conversions obtained at $350^{\circ} \mathrm{C}$ in the presence of MF.

\begin{tabular}{|c|c|c|c|c|c|}
\hline Sample & $x_{\mathrm{NO}}\left(T=350^{\circ} \mathrm{C}\right) / \%$ & $m_{\mathrm{MF}} / \mathrm{g}$ & $C_{\text {NOred }} / \mathrm{mmol} \mathrm{g}^{-1}$ & $C_{\text {NOred }} \times 10^{-3} / \mathrm{mmol} \mathrm{m}^{-2}$ & $C_{\text {NOred }} / \mathrm{mmol} \mathrm{gCu}^{-1}$ \\
\hline MF_10Cu & 35 & 2.58 & 0.45 & 0.74 & 13.6 \\
\hline MF_M_10Cu & 90 & 3.95 & 0.76 & 1.40 & 16.6 \\
\hline MF_U_10Cu & 94 & 2.92 & 1.07 & 1.35 & 17.1 \\
\hline
\end{tabular}

NO conversions were determined as a function of $\mathrm{mmol}$ of $\mathrm{NO}$ per gram of foam $\left(\mathrm{mmol} \mathrm{g}^{-1}\right.$ ) since the mass of each MF under study is slightly different; therefore, in Figure 6, it can be seen that MF_10 $\mathrm{Cu}$ achieves a very different conversion value while MF_M_10Cu and MF_U_10Cu exhibit similar profiles and the maximum conversion is close to each other. The achievement of these results is due to the fact that doping carbon materials with nitrogen increases the density of electrons and the ability to donate them, which results in a better catalytic activity [15]. Other authors carried out studies on the oxidation of $\mathrm{NO}$ and also proved that materials with nitrogen promote $\mathrm{NO}$ adsorption $[17,26,36,37]$. In Table 3, it is clear that MF_U_Cu stands out in the catalytic activity of reducing NO in relation to MF_M_10Cu and MF_10Cu, since this material was able to reduce $1.07 \mathrm{mmol}$ $\mathrm{g}^{-1}$. The converted amount of NO per specific surface area increases from MF prepared without nitrogen solution to MF synthetized with nitrogen solution. However, the specific surface area value decreases when melamine is impregnated and increases when urea is introduced into the MF structure. Moreover, the intrinsic activity of the copper on the urea doped sample is higher than the remaining, revealing an improved interaction between surface nitrogen species and the metal catalyst using this precursor. These results reveal that factors such as specific surface area, amount of copper, amount of oxygen and amount of catalyst have influence in the catalytic results.

To determine if higher amounts of copper results in better catalytic activity in reducing NO, experiments were carried out with MF_U with 10, 20 and $30 \% \mathrm{Cu}$. These contents correspond to the amount of copper placed in the solution as a function of the mass of the MF; however, as the sample does not fully adsorb all copper in the solution, the MF samples have an amount of copper lower than expected (Table 2).

According to the data presented in Figure 7, the temperature required to reach the same NO conversion value decreases with the increasing content of copper in the MF. In MF_U_20Cu and MF_U_30Cu, the NO reduction curves are identical, with a mismatch between them caused at low temperatures by the chemically adsorbed $\mathrm{O}_{2}$ on the surface and at high temperatures due to the better performance in the conversion of $\mathrm{NO}$ with the 
increase in the amount of copper in the sample [38]. This confirms that the presence of $\mathrm{Cu}$ is important as the greater the amount of copper in the catalysts the better the catalytic performance for NO reduction.

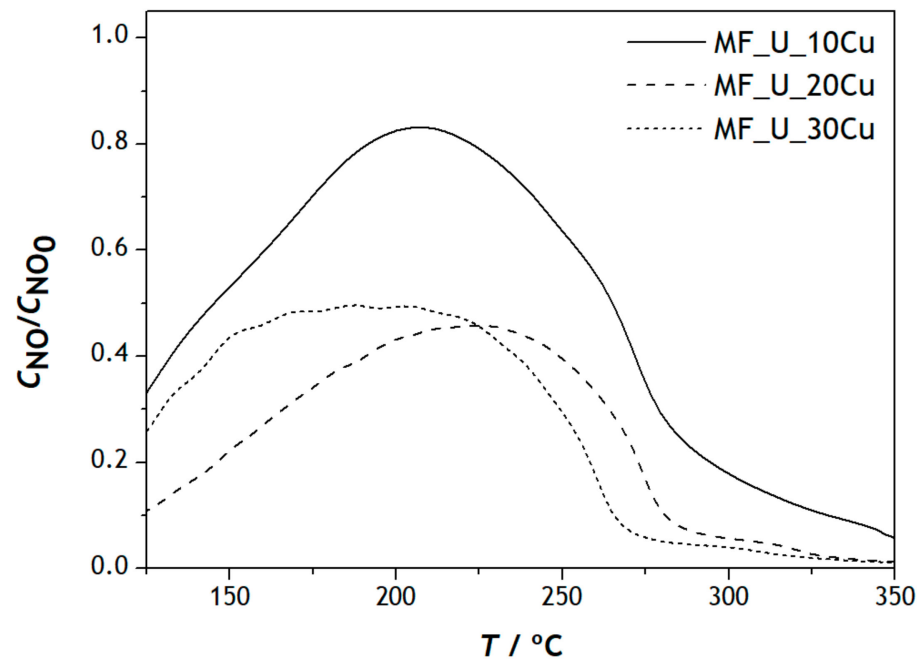

Figure 7. NO concentration in the presence of samples with 10, 20 and 30\% Cu with [NO] = $1000 \mathrm{ppm}$ in He with $5 \%$ of $\mathrm{O}_{2}$.

The influence of the type of structured material (melamine foam or cordierite monolith) used to support the catalysts is shown in Figure 8.

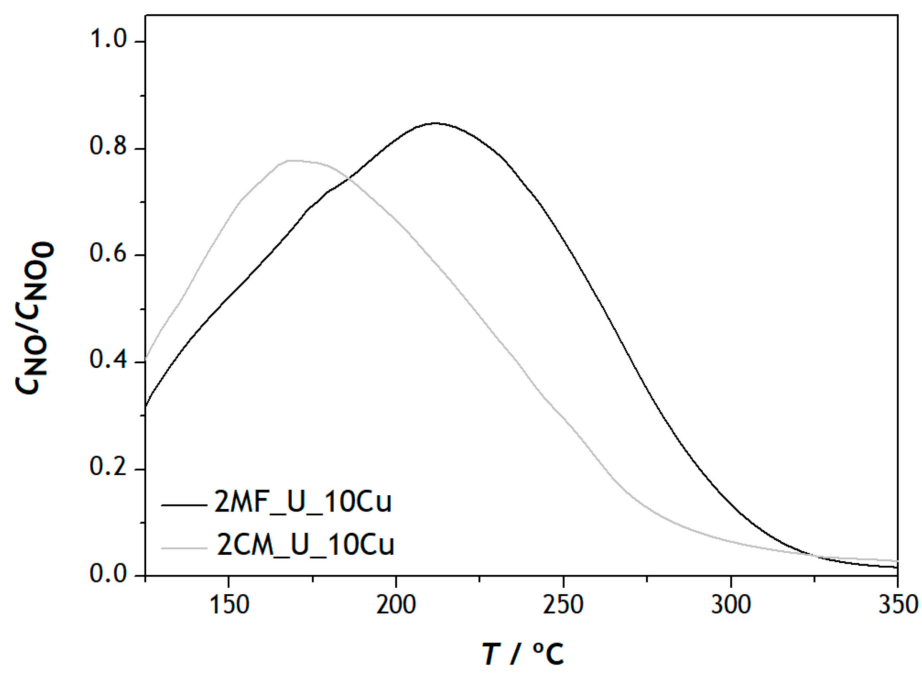

Figure 8. NO concentration in the presence of $\mathrm{MF}$ and $\mathrm{CM}$ with $[\mathrm{NO}]=1000 \mathrm{ppm}$ in $\mathrm{He}$ with $5 \%$ of $\mathrm{O}_{2}$.

The NO reduction starts at $175^{\circ} \mathrm{C}$ over the catalyst supported on $\mathrm{CM}$, while using $\mathrm{MF}$ as support, the catalytic activity begins at about $225^{\circ} \mathrm{C}$. The best performance of the 2CM_U_10Cu sample is verified up to $325^{\circ} \mathrm{C}$, as the two materials reach the same conversion at that temperature. Although the results seem more attractive in relation to the catalyst structured with melamine foam, further studies on the characterization and other parameters of the NO reduction reaction with the catalyst structured with cordierite monoliths would be needed to discuss its catalytic performance [39]. 


\subsubsection{Stability Assay}

A long-term test was carried out to verify the catalyst stability. Figure 9 shows the NO conversion profile obtained during $75 \mathrm{~h}$ at $300{ }^{\circ} \mathrm{C}$ for sample MF_U_30Cu.

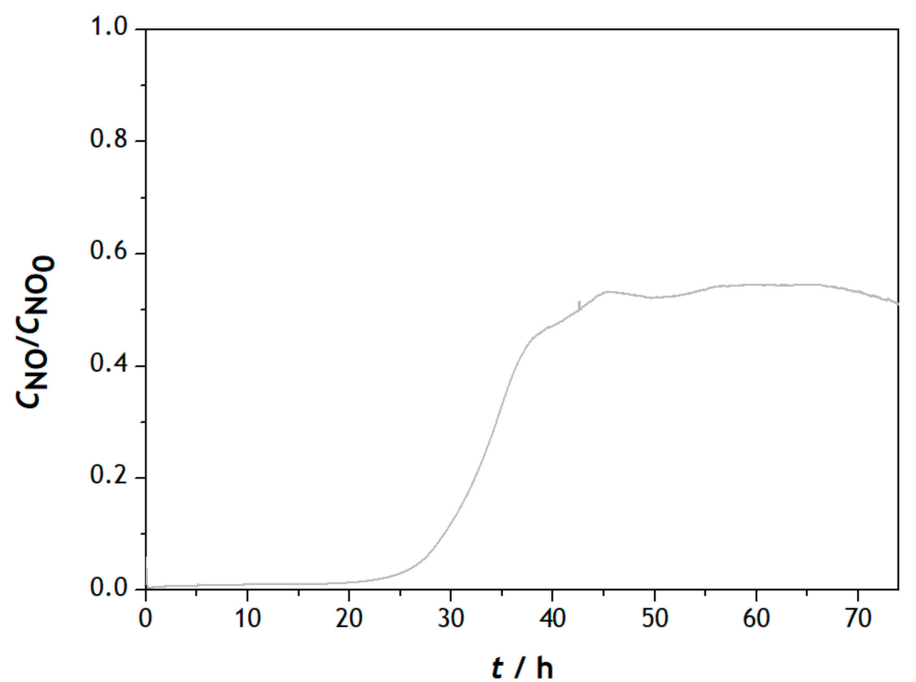

Figure 9. NO concentration in a stability assay at $300{ }^{\circ} \mathrm{C}$ for $75 \mathrm{~h}$.

Table 4 indicates the textural properties before and after the stability test.

Table 4. Textural properties of the MF_U_30Cu before and after the stability assay.

\begin{tabular}{cccccc}
\hline & $m_{\mathbf{M F} / \mathbf{g}}$ & $S_{\mathbf{B E T}} / \mathbf{m}^{\mathbf{2}} \mathbf{g}^{-\mathbf{1}}$ & $S_{\text {meso }} / \mathbf{m}^{\mathbf{2}} \mathbf{g}^{-\mathbf{1}}$ & $V_{\text {micro }} / \mathbf{c m}^{\mathbf{3}} \mathbf{g}^{-1}$ & $V_{\mathbf{p ~ p / p o = 0 . 9 5}} / \mathbf{c m}^{3} \mathbf{g}^{-\mathbf{1}}$ \\
\hline Before reaction & 3.05 & 471 & 48 & 0.18 & 0.22 \\
After reaction & 1.79 & 796 & 140 & 0.27 & 0.35 \\
\hline
\end{tabular}

From the beginning of the experiment the sample showed $98 \%$ conversion at $300{ }^{\circ} \mathrm{C}$ and the catalyst deactivation started after $20 \mathrm{~h}$ of reaction. Between 20 and $40 \mathrm{~h}$, the catalyst loses activity, reaching a level of approximately $50 \%$, which remains constant for the remaining hours of the test. With the catalyst deactivation, the carbon material significantly lost its mass causing the textural properties change (surface areas and pore volume increased). These results indicate that the materials under study are stable and catalytically active over a long period of time.

\section{Materials and Methods}

\subsection{Materials Synthesis}

Powder Metal Catalysts

Carbon xerogels (CX), introduced by Pekala in 1989 [40], are porous materials obtained by carbonization of an organic gel that occurs through the sol-gel polycondensation of organic monomers, such as resorcinol $\left(\mathrm{C}_{6} \mathrm{H}_{6} \mathrm{O}_{2}\right)$ (Sigma-Aldrich, Darmstadt, Germany, $99 \%$ ) and formaldehyde $\left(\mathrm{CH}_{2} \mathrm{O}\right)$ (Sigma-Aldrich, Darmstadt, Germany, 37\% in $\left.\mathrm{H}_{2} \mathrm{O}\right)$, using a solvent and a basic catalyst as a reaction promoter [40-42].

$\mathrm{CX}$ were prepared at room temperature with an initial $\mathrm{pH}$ of 5.3 through the sol-gel polycondensation [37]. Two nitrogen precursors were used during the synthesis process, melamine (M) (99\% Fluka, Buchs, Switzerland) and urea (U) (VWR, 100\%), to prepare the nitrogen-doped carbon xerogels (CX_N). The CX heat treatment was carried under a $\mathrm{N}_{2}$ flowrate of $100 \mathrm{~cm}^{3} \mathrm{~min}^{-1}$ through three temperature increments at a heating rate of $2{ }^{\circ} \mathrm{C} \mathrm{min}-1$. The plateaus were 200,300 and $900{ }^{\circ} \mathrm{C}$ for 2,1 and $2 \mathrm{~h}$, respectively. Transition metal-carbon xerogels (CX_TM) were prepared by incipient impregnation using three 
metallic precursors: iron nitrate $\left(\mathrm{Fe}\left(\mathrm{NO}_{3}\right)_{3} \cdot 9 \mathrm{H}_{2} \mathrm{O}\right)$ (Sigma-Aldrich, 98\%), nickel nitrate $\left(\mathrm{Ni}\left(\mathrm{NO}_{3}\right)_{2} \cdot 6 \mathrm{H}_{2} \mathrm{O}\right)$ (Sigma-Aldrich, Darmstadt, Germany, crystalline) and copper nitrate $\left(\mathrm{Cu}\left(\mathrm{NO}_{3}\right)_{2} \cdot 3 \mathrm{H}_{2} \mathrm{O}\right)$ (Sigma-Aldrich, Darmstadt, Germany, 99-104\%). The amount of impregnated metal corresponds to $10 \%(w t . \%)$ and the $\mathrm{CX}$ and $\mathrm{CX} \_\mathrm{N}(\mathrm{pH}=5.3)$ previously prepared were used as support. The CX soaked in the metal precursor solution was left for $1.5 \mathrm{~h}$ in an ultrasonic bath. Finally, the sample was placed in the oven for $24 \mathrm{~h}$. The thermal treatment of CX_TM was carried out under a flowrate of $\mathrm{N}_{2}$ and $\mathrm{H}_{2}$ of $100 \mathrm{~cm}^{3} \mathrm{~min}^{-1}$ at a heating rate of $10{ }^{\circ} \mathrm{C} \mathrm{min}^{-1}$. The iron and nickel impregnated $\mathrm{CX}$ were heated from room temperature to $400{ }^{\circ} \mathrm{C}$ and the copper impregnated CX up to $300{ }^{\circ} \mathrm{C}$ under the flowrate of $\mathrm{N}_{2}$. After reaching the required temperature, the $\mathrm{N}_{2}$ flowrate was maintained for $1 \mathrm{~h}$. Then the sample was reduced in $\mathrm{H}_{2}$ for $3 \mathrm{~h}$.

Melamine foams (MF) (Basotect, BASF, Bucharest, Romania) and cordierite monoliths (CM) (Corning, Sigma-Aldrich, Darmstadt, Germany) were used as a template of the structured catalyst. Initially, MF/CM were cut with a diameter of $2 \mathrm{~cm}$ of and $4 \mathrm{~cm}$ of height. The supports were immersed in $\mathrm{CX}$ solutions with $\mathrm{pH}=5.3$ for $2 \mathrm{~min}$ and then placed in the oven for 3 days at $85^{\circ} \mathrm{C}$. After the drying period in the oven, the materials were heat treated in the same way as the CX. To carry out the metal impregnation on the supports, the necessary mass of copper nitrate corresponding to 10, 20 and 30\% (wt.\%) of the metal was determined. The samples were immersed in the corresponding solutions and left to stir for $24 \mathrm{~h}$. Oven drying and heat treatment are equivalent to those described for CX_TM. To name the samples, the following order was followed: support (CX, MF or $\mathrm{CM})$, nitrogen precursor ( $\mathrm{M}$ or $\mathrm{U}$ ) and amount (10, 20 or 30) of impregnated metal (Fe, Ni or $\mathrm{Cu})$ (Ex: MF_U_10Cu).

\subsection{Characterization Techniques}

Nitrogen adsorption-desorption equilibrium isotherms at $-196{ }^{\circ} \mathrm{C}$ were performed in a Quantachrome Instruments equipment (Quantachrome Instruments, Boynton Beach, USA) to determine the textural properties of the synthesized materials. The BET method was applied to calculate the specific surface area $\left(S_{\mathrm{BET}}\right)$, whereas the specific surface area of mesopores $\left(S_{\text {meso }}\right)$ and the specific micropore volume $\left(V_{\text {micro }}\right)$ were determined by the t-method.

The nitrogen content of the prepared materials was determined by elemental analysis (EA) in the CHNS vario MICRO cube analyzer (Kalkar, Germany).

Inductively Coupled Plasma Atomic Emission Spectrometry (ICP-OES), using the ICPE-9000 spectrometer (Shimadzu, Auckland, New Zealand), allowed determining the copper concentration present in MF.

A Thermo Scientific Escalab 250Xi (Porto, Portugal) spectrometer was used for X-ray photoelectron spectroscopy (XPS), using a monochrome and microfocused Al K $\alpha$ X-ray source. The fit of the spectra peaks was performed using the Thermo Fisher Scientific (Porto, Portugal) Avantage program.

Thermogravimetric analysis (TGA) was performed on the Netzsch STA 409 PC/PG (Selb, Germany) equipment using a dynamic method. The samples were heated to $900{ }^{\circ} \mathrm{C}$ using an air flowrate of $20 \mathrm{~cm}^{3} \mathrm{~min}^{-1}$.

The morphology of the materials and the adhesion of carbon to MF was observed by scanning electron microscopy (SEM) on a Quanta 650 FEG microscope (FEI, Marietta, GA, USA).

\subsection{Catalytic Tests}

The tests using the powder materials were carried out in a U-shaped fixed bed microreactor with a diameter of $0.7 \mathrm{~cm}$, where $200 \mathrm{mg}$ of catalyst with a particle size between 200-500 $\mu \mathrm{m}$ was placed. In the catalytic tests using the structured catalysts, a U-shaped reactor with a diameter of $2.6 \mathrm{~cm}$ was used. The reduction of $\mathrm{NO}$ was carried out under a total flow rate of $100 \mathrm{~cm}^{3} \mathrm{~min}^{-1}$ with a concentration of $1000 \mathrm{ppm} \mathrm{NO}$ in $\mathrm{He}$ and $5 \% \mathrm{O}_{2}$ (Figure A3) in the temperature range of 125 to $350{ }^{\circ} \mathrm{C}$ with a heating ramp of $3{ }^{\circ} \mathrm{C} \mathrm{min}-1$. 
$\mathrm{NO}, \mathrm{NO}_{2}$ and $\mathrm{NO}_{x}$ concentrations were measured on a Thermo Fisher Scientific $\mathrm{NO}-\mathrm{NO}_{2}-$ $\mathrm{NO}_{x}$ analyzer.

The conversion of $\mathrm{NO}\left(x_{\mathrm{NO}}\right)$ was calculated according to Equation (3).

$$
x_{\mathrm{NO}}=\left(1-\frac{c_{\mathrm{NO}}}{c_{\mathrm{NO}_{0}}}\right) \times 100
$$

\section{Conclusions}

Nitrogen oxides are considered one of the pollutants that cause the greatest concern in terms of atmospheric contamination. In this sense, the main objective of this work was the synthesis and characterization of structured carbon catalysts, introducing metals and nitrogen groups, catalytically active in the reduction of $\mathrm{NO}$ to contribute to the reduction of its emissions.

In the NO reduction tests performed with $\mathrm{CX}$, the presence of transition metals in the structure was essential for catalytic activity and the introduction of nitrogenous groups in the CX structure, using melamine as a precursor, enhanced the catalytic results. The MF samples with urea showed the best performance in reducing NO and simultaneously had the highest content of copper in their structure, so it appears that the incorporation/concentration of copper in the materials is a determining factor in the catalytic reduction of $\mathrm{NO}$ into $\mathrm{N}_{2}$. Cordierite monoliths are a promising support alternative for the catalytic activity to be favored at low temperatures.

Although CX, MF and CM, have high conversions in the catalytic reduction of NO to $\mathrm{N}_{2}$ at temperatures between 300 and $350{ }^{\circ} \mathrm{C}$, structured catalysts represent a preferable alternative to powder catalysts because they have better thermal stability and lower pressure drop. This advantage is fundamental for applications in industrial processes.

Author Contributions: Conceptualization, J.P.S.S., J.R. and O.S.G.P.S.; methodology, J.P.S.S., J.R. and O.S.G.P.S.; investigation, M.B.S.F. and J.P.S.S.; resources J.P.S.S., M.F.R.P. and O.S.G.P.S., writingoriginal draft preparation, M.B.S.F.; writing—review and editing, M.B.S.F., J.P.S.S., J.R., O.S.G.P.S. and M.F.R.P.; supervision, J.R. and O.S.G.P.S.; funding acquisition, J.P.S.S., M.F.R.P. and O.S.G.P.S. All authors have read and agreed to the published version of the manuscript.

Funding: This work is a result of project 2SMART-engineered Smart materials for Smart citizens, with reference NORTE-01-0145-FEDER-000054, supported by Norte Portugal Regional Operational Programme (NORTE 2020), under the PORTUGAL 2020 Partnership Agreement, through the European Regional Development Fund (ERDF) and is also financially supported by: Base-UIDB/50020/2020 and Programmatic-UIDP/50020/2020 Funding of LSRE-LCM, funded by national funds through FCT/MCTES (PIDDAC). OSGPS acknowledges FCT funding under the Scientific Employment Stimulus-Institutional Call CEECINST/00049/2018.

Conflicts of Interest: The authors declare no conflict of interest. 


\section{Appendix A}

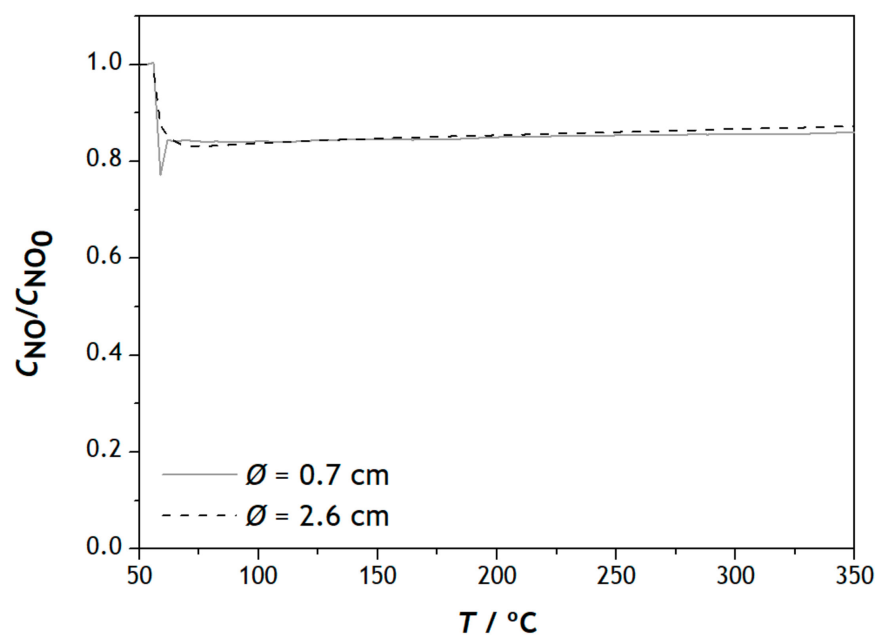

Figure A1. NO concentration in blank tests with $[\mathrm{NO}]=1000 \mathrm{ppm}$ in $\mathrm{He}$ with $5 \%$ of $\mathrm{O}_{2}$.

The NO conversion profile shown in Figure A1 is similar in the two reactors, where the decreasing peaks between 50 and $75{ }^{\circ} \mathrm{C}$ result of the experimental setup configuration, namely the passage through the $\mathrm{NO}-\mathrm{NO}_{2}-\mathrm{NO}_{x}$ analyzer of the dead volume of air present in the reactors and piping at the beginning of the reaction. The presence of $\mathrm{O}_{2}$ promotes the reduction of $\mathrm{NO}$ and, therefore, a lower $c_{N O} / c_{N O_{0}}$ plateau is observed compared to the initial concentration of NO, $1000 \mathrm{ppm}$. The homogeneous conversion of NO differs only $1 \%$ between the two tests, being $14 \%$ for the $0.7 \mathrm{~cm}$ reactor and $13 \%$ for the $2.6 \mathrm{~cm}$ reactor.

To understand the oscillations of the concentration along the studied reactions, two tests were carried out changing the initial temperature of the reaction, 25 and $50{ }^{\circ} \mathrm{C}$, using the CX_Cu catalyst (Figure A2).

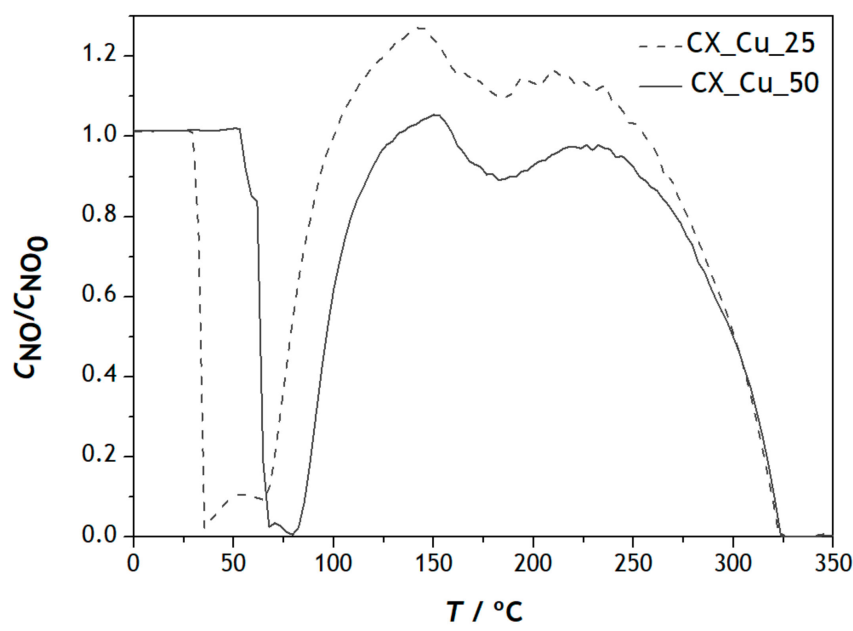

Figure A2. NO concentration in the presence of CX_Cu with initial reaction temperature of 25 and $50{ }^{\circ} \mathrm{C}$ and $[\mathrm{NO}]=1000 \mathrm{ppm}$ in $\mathrm{He}$ with $5 \%$ of $\mathrm{O}_{2}$.

The depressions observed between 30 and $100^{\circ} \mathrm{C}$ suggest that $\mathrm{NO}$ is first adsorbed on the surface and then desorbed with increasing temperature, causing an increase in NO concentration above 1000 ppm [43].

From Figure A2, it can be seen that in the reaction starting at $25^{\circ} \mathrm{C}$, there is greater adsorption of $\mathrm{NO}$ in the initial phase than in the test started at $50{ }^{\circ} \mathrm{C}$. In the desorption part, exactly the same is verified, with a greater amount of $\mathrm{NO}$ desorbed in the test carried 
out at the lower temperature. However, the amount of adsorbed and desorbed NO at the beginning of the reaction does not interfere with the catalytic results obtained at higher temperatures, since from $300{ }^{\circ} \mathrm{C}$ the two curves overlap and give the same NO conversion value.

Between 150 and $225{ }^{\circ} \mathrm{C}$ there is a slight decrease followed by an increase in the concentration of $\mathrm{NO}$; this change can be justified based on the oxidation states of copper, since in the experiments with the other metals this behavior was not observed [44].

In Figure $\mathrm{A} 3$, the conversion curves of $\mathrm{NO}$ and $\mathrm{NO}_{2}$ obtained in the catalytic tests of $\mathrm{NO}$ reduction are represented to evaluate which would be the reaction products.

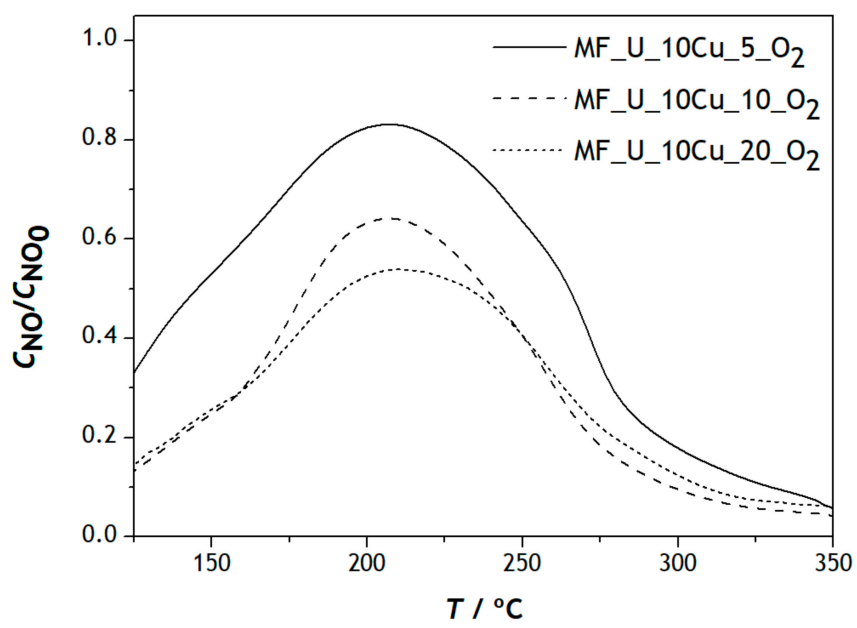

Figure A3. $\mathrm{NO}$ and $\mathrm{NO}_{2}$ concentrations in the presence of $\mathrm{CX}$ and $\mathrm{CX} \_\mathrm{N}$ with and without metals with $[\mathrm{NO}]=1000 \mathrm{ppm}$ in $\mathrm{He}$ with $5 \%$ of $\mathrm{O}_{2}$.

As insignificant amounts of $\mathrm{NO}_{2}$ (grey lines) were detected as reaction products in all temperature ranges, under these experimental conditions, it is assumed that $\mathrm{N}_{2}$ is the only observed reaction product.

The presence of $\mathrm{O}_{2}$ in the $\mathrm{NO}$ current causes the amount of reduced $\mathrm{NO}$ to increase, but the ideal amount of oxygen is not known [34]. Therefore, the tests described in Figure A4 were obtained to verify if the increase in the concentration of $\mathrm{O}_{2}$ in the gas stream influenced the performance of the catalysts in reducing NO. The behavior of MF_U_10Cu was evaluated in the presence of 5,10 and $20 \% \mathrm{O}_{2}$.

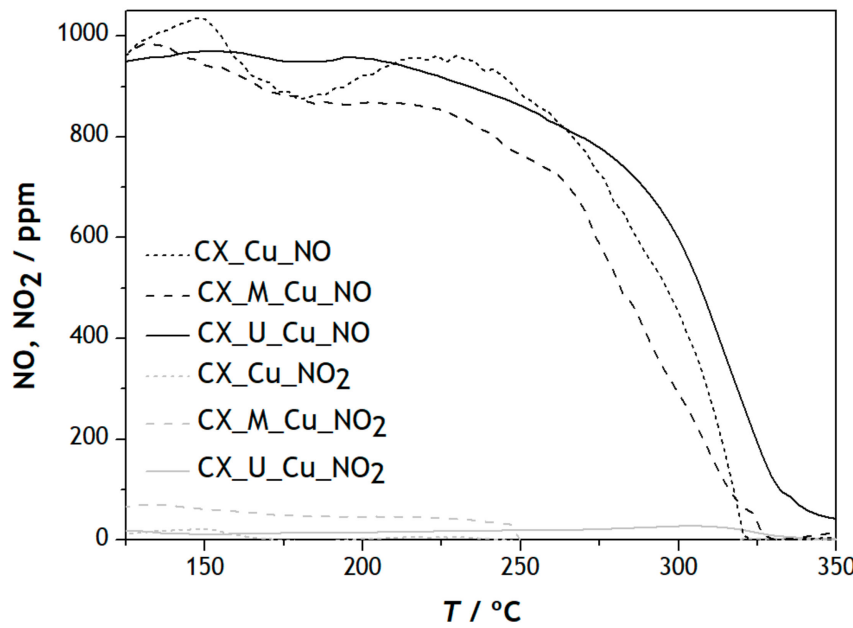

Figure A4. NO concentration in sample MF_U_10Cu with [NO] = 1000 ppm in He with 5, 10 and $20 \%$ of $\mathrm{O}_{2}$. 
Table A1 presents the catalyst mass lost during the reaction with MF_U_10Cu in the presence of 5,10 and $20 \%$ of $\mathrm{O}_{2}$.

Table A1. Catalyst mass lost during the reaction in the presence of MF_U_10Cu samples under 5, 10 and $20 \% \mathrm{O}_{2}$.

\begin{tabular}{cc}
\hline Sample & $m_{\text {lost_in_reaction }} / \%$ \\
\hline MF_U_10Cu_5_O & 1.6 \\
MF_U_10Cu_10_O & 4.2 \\
MF_U_10Cu_20_O & 7.2 \\
\hline
\end{tabular}

Analyzing the results of Figure A4, between 200 and $250{ }^{\circ} \mathrm{C}$ the reduction of NO increases with the increase in the concentration of $\mathrm{O}_{2}$ used; however, for temperatures above $250{ }^{\circ} \mathrm{C}$ the increase in the concentration of $\mathrm{O}_{2}$ is significant when it increases from 5 to $10 \%$ but increasing this parameter beyond $10 \%$ has no positive influence on the NO conversion. The maximum conversion of NO obtained for 5 and $10 \%$ is $95 \%$ at a temperature of 350 and $338{ }^{\circ} \mathrm{C}$, respectively. The mass of the MF samples lost during the reaction increases with the increase in the concentration of $\mathrm{O}_{2}$ in the gas stream due to the gasification of the sample, which shows that the samples are less stable in the presence of a greater amount of $\mathrm{O}_{2}$. Although the maximum conversion temperature in the MF_U_10Cu_10_O ${ }_{2}$ test is slightly lower than in the MF_U_10Cu_5_O $\mathrm{O}_{2}$ test, the results obtained at $5 \% \mathrm{O}_{2}$ are also quite attractive and the stability of the samples is higher, which makes the increase of the oxygen concentration in the NO stream unfavorable.

\section{References}

1. Lu, P.; Li, C.; Zeng, G.; He, L.; Peng, D.; Cui, H.; Li, S.; Zhai, Y. Low temperature selective catalytic reduction of NO by activated carbon fiber loading lanthanum oxide and ceria. Appl. Catal. B Environ. 2010, 96, 157-161. [CrossRef]

2. Wojciechowska, M.; Lomnicki, S. Nitrogen oxides removal by catalytic methods. Clean Technol. Environ. Policy 1999, 1, 237-247. [CrossRef]

3. Jędrusik, M.; Łuszkiewicz, D.; Świerczok, A. Methods to Reduce Mercury and Nitrogen Oxides Emissions from Coal Combustion Processes; IntechOpen: London, UK, 2020.

4. Saramok, M.; Szymaszek, A.; Inger, M.; Antoniak-Jurak, K.; Samojeden, B.; Motak, M. Modified zeolite catalyst for a nox selective catalytic reduction process in nitric acid plants. Catalysts 2021, 11, 450. [CrossRef]

5. Kwon, D.W.; Park, K.H.; Ha, H.P.; Hong, S.C. The role of molybdenum on the enhanced performance and SO2 resistance of V / Mo-Ti catalysts for NH 3 -SCR. Appl. Surf. Sci. 2019, 481, 1167-1177. [CrossRef]

6. Raja, S.; Alphin, M.S. Systematic effects of Fe doping on the activity of V2O5/TiO2-carbon nanotube catalyst for NH3-SCR of $\mathrm{NO}_{x}$. J. Nanopart. Res. 2020, 22, 190. [CrossRef]

7. Liu, K.; Yu, Q.; Wang, B.; Qin, Q.; Wei, M.; Fu, Q. Low temperature selective catalytic reduction of nitric oxide with urea over activated carbon supported metal oxide catalysts. Environ. Technol. 2020, 41, 808-821. [CrossRef]

8. Mrad, R.; Aissat, A.; Cousin, R.; Courcot, D.; Siffert, S. Catalysts for $\mathrm{NO}_{\mathrm{x}}$ selective catalytic reduction by hydrocarbons (HC-SCR). Appl. Catal. A Gen. 2015, 504, 542-548. [CrossRef]

9. Resitoglu, I.A.; Keskin, A. Hydrogen applications in selective catalytic reduction of $\mathrm{NO}_{\mathrm{x}}$ emissions from diesel engines. Int. J. Hydrogen Energy 2017, 42, 23389-23394. [CrossRef]

10. Dasireddy, V.D.B.C.; Likozar, B. Selective catalytic reduction of $\mathrm{NO}_{\mathrm{x}}$ by $\mathrm{CO}$ over bimetallic transition metals supported by multi-walled carbon nanotubes (MWCNT). Chem. Eng. J. 2017, 326, 886-900. [CrossRef]

11. Shu, Y.; Zhang, F.; Wang, F.; Wang, H. Catalytic reduction of $\mathrm{NO}_{\mathbf{x}}$ by biomass-derived activated carbon supported metals. Chin. J. Chem. Eng. 2018, 26, 2077-2083. [CrossRef]

12. Catalão, R.A.; Maldonado-Hódar, F.J.; Fernandes, A.; Henriques, C.; Ribeiro, M.F. Reduction of NO with metal-doped carbon aerogels. Appl. Catal. B Environ. 2009, 88, 135-141. [CrossRef]

13. Li, X.; Wang, H.; Shao, G.; Wang, G.; Lu, L. Low temperature reduction of NO by activated carbons impregnated with Fe based catalysts. Int. J. Hydrogen Energy 2019, 44, 25265-25275. [CrossRef]

14. Bailón-García, E.; Drwal, E.; Grzybek, T.; Henriques, C.; Ribeiro, M.F. Catalysts based on carbon xerogels with high catalytic activity for the reduction of $\mathrm{NO}_{x}$ at low temperatures. Catal. Today 2020, 356, 301-311. [CrossRef]

15. Zainul Abidin, A.F.; Loh, K.S.; Wong, W.Y.; Mohamad, A.B. Nitrogen-doped carbon xerogels catalyst for oxygen reduction reaction: Improved structural and catalytic activity by enhancing nitrogen species and cobalt insertion. Int. J. Hydrogen Energy 2019, 44, 28789-28802. [CrossRef] 
16. Drage, T.C.; Arenillas, A.; Smith, K.M.; Pevida, C.; Piippo, S.; Snape, C.E. Preparation of carbon dioxide adsorbents from the chemical activation of urea-formaldehyde and melamine-formaldehyde resins. Fuel 2007, 86, 22-31. [CrossRef]

17. Gorgulho, H.F.; Gonçalves, F.; Pereira, M.F.R.; Figueiredo, J.L. Synthesis and characterization of nitrogen-doped carbon xerogels. Carbon 2009, 47, 2032-2039. [CrossRef]

18. Shi, Y.; Liu, G.; Jin, R.; Xu, H.; Wang, Q.; Gao, S. Carbon materials from melamine sponges for supercapacitors and lithium battery electrode materials: A review. Carbon Energy 2019, 1, 253-275. [CrossRef]

19. Tighe, C.J.; Dennis, J.S.; Hayhurst, A.N.; Twigg, M.V. The reactions of NO with diesel soot, fullerene, carbon nanotubes and activated carbons doped with transition metals. Proc. Combust. Inst. 2009, 32, 1989-1996. [CrossRef]

20. Illán-Gómez, M.J.; Raymundo-Piñero, E.; García-García, A.; Linares-Solano, A.; Salinas-Martínez de Lecea, C. Catalytic NO(x) reduction by carbon supporting metals. Appl. Catal. B Environ. 1999, 20, 267-275. [CrossRef]

21. Govender, S.; Friedrich, H.B. Monoliths: A review of the basics, preparation methods and their relevance to oxidation. Catalysts 2017, 7, 62. [CrossRef]

22. Cybulski, A.; Moulijn, J.A. Structured Catalysts and Reactors, 2nd ed.; CRC Press: Boca Raton, FL, USA, 2005.

23. Twigg, M.V.; Richardson, J.T. Fundamentals and applications of structured ceramic foam catalysts. Ind. Eng. Chem. Res. 2007, 46, 4166-4177. [CrossRef]

24. Santos, A.F.X.G. Catalisadores Heterogéneos para a Produção de Biodiesel. Master's Thesis, Technical University of Lisbon, Lisbon, Portugal, November 2007.

25. Restivo, J.; Orge, C.A.; Guedes Gorito dos Santos, A.S.; Soares, O.S.G.P.; Pereira, M.F.R. Nanostructured Layers of Mechanically Processed Multiwalled Carbon Nanotubes for Catalytic Ozonation of Organic Pollutants. ACS Appl. Nano Mater. 2020, 3 , 5271-5284. [CrossRef]

26. Cimino, S.; Cepollaro, E.M.; Lisi, L.; Fasolin, S.; Musiani, M.; Vázquez-Gómez, L. Ru/ce/ni metal foams as structured catalysts for the methanation of $\mathrm{CO}_{2}$. Catalysts 2021, 11, 13. [CrossRef]

27. Restivo, J.; Órfão, J.J.M.; Pereira, M.F.R.; Vanhaecke, E.; Rönning, M.; Iouranova, T.; Kiwi-Minsker, L.; Armenise, S.; Garcia-Bordejé, E. Catalytic ozonation of oxalic acid using carbon nanofibres on macrostructured supports. Water Sci. Technol. 2012, 65, 1854-1862. [CrossRef] [PubMed]

28. Zou, X.; Lou, S.; Yang, C.; Liu, N.; Wang, X.; Shi, L.; Meng, X. Catalytic Oxidation of NO on N-doped Carbon Materials at Low Temperature. Catal. Lett. 2021, 151, 487-496. [CrossRef]

29. García-Valverde, M.T.; Chatzimitakos, T.; Lucena, R.; Cárdenas, S.; Stalikas, C.D. Melamine sponge functionalized with ureaformaldehyde co-oligomers as a sorbent for the solid-phase extraction of hydrophobic analytes. Molecules 2018, $23,2595$. [CrossRef]

30. Soares, O.S.G.P.; Rocha, R.P.; Gonçalves, A.G.; Figueiredo, J.L.; Órfão, J.J.M.; Pereira, M.F.R. Easy method to prepare N-doped carbon nanotubes by ball milling. Carbon 2015, 91, 114-121. [CrossRef]

31. Bulushev, D.A.; Chuvilin, A.L.; Sobolev, V.I.; Stolyarova, S.G.; Shubin, Y.V.; Asanov, I.P.; Ishchenko, A.V.; Magnani, G.; Riccò, M.; Okotrub, A.V.; et al. Copper on carbon materials: Stabilization by nitrogen doping. J. Mater. Chem. A 2017, 5, 10574-10583. [CrossRef]

32. Rocha, R.P.; Soares, O.S.G.P.; Gonçalves, A.G.; Órfão, J.J.M.; Pereira, M.F.R.; Figueiredo, J.L. Different methodologies for synthesis of nitrogen doped carbon nanotubes and their use in catalytic wet air oxidation. Appl. Catal. A Gen. 2017, 548, 62-70. [CrossRef]

33. Bai, H.L.; Jiang, E.Y. Improvement of the thermal stability of amorphous carbon films by incorporation of nitrogen. Thin Solid Film. 1999, 353, 157-165. [CrossRef]

34. Jia, Q.; Ghoshal, S.; Li, J.; Liang, W.; Meng, G.; Che, H.; Zhang, S.; Ma, Z.F.; Mukerjee, S. Metal and Metal Oxide Interactions and Their Catalytic Consequences for Oxygen Reduction Reaction. J. Am. Chem. Soc. 2017, 139, 7893-7903. [PubMed]

35. Fangueiro, R. Materiais à Base de Carbono; Fibrenamics Intell: Guimarães, Portugal, 2019; pp. 1-9.

36. Yasuda, E.; Inagaki, M.; Kaneko, K.; Endo, M.; Oya, A.; Tanabe, Y. Carbon Alloys: Novel Concepts to Develop Carbon Science and Technology; Elsevier: Amsterdam, The Netherlands, 2003.

37. Sousa, J.P.S.; Pereira, M.F.R.; Figueiredo, J.L. NO oxidation over nitrogen doped carbon xerogels. Appl. Catal. B Environ. 2012, 125, 398-408. [CrossRef]

38. Sousa, J.P.S.; Pereira, M.F.R.; Figueiredo, J.L. Catalytic oxidation of $\mathrm{NO}$ to $\mathrm{NO}_{2}$ on $\mathrm{N}$-doped activated carbons. Catal. Today 2011, 176, 383-387. [CrossRef]

39. Heck, R.M.; Gulati, S.; Farrauto, R.J. The application of monoliths for gas phase catalytic reactions. Chem. Eng. J. 2001, 82, 149-156. [CrossRef]

40. Pekala, R.W. Organic aerogels from the polycondensation of resorcinol with formaldehyde. J. Mater. Sci. 1989, 24, 3221-3227. [CrossRef]

41. Rey-Raap, N.; Arenillas, A.; Menéndez, J.A. A visual validation of the combined effect of $\mathrm{pH}$ and dilution on the porosity of carbon xerogels. Microporous Mesoporous Mater. 2016, 223, 89-93. [CrossRef]

42. Canal-Rodríguez, M.; Arenillas, A.; Rey-Raap, N.; Ramos-Fernández, G.; Martín-Gullón, I.; Menéndez, J.A. Graphene-doped carbon xerogel combining high electrical conductivity and surface area for optimized aqueous supercapacitors. Carbon 2017, 118, 291-298. [CrossRef] 
43. Sousa, J.P.S.; Pereira, M.F.R.; Figueiredo, J.L. Modified activated carbon as catalyst for NO oxidation. Fuel Process. Technol. 2013, 106, 727-733. [CrossRef]

44. Lee, S.K.; Hsu, H.C.; Tuan, W.H. Oxidation behavior of copper at a temperature below $300{ }^{\circ} \mathrm{C}$ and the methodology for passivation. Mater. Res. 2016, 19, 51-56. [CrossRef] 